\title{
MODERNISASI HUKUM NOTARIS MASA DEPAN: KAJIAN HUKUM TERHADAP KEMUNGKINAN CYBERNOTARY DI INDONESIA
}

\author{
Edmon Makarim
}

\begin{abstract}
To prevent fraud (fraud) is developing the use of an electronic authentication methods (electronic authentication) technology embodied in the Electronic Signature and Electronic Certificates. ("SE") as a security system transactions made through an electronic communication system. For the purposes effectiveness, it has many functions and role of the state empowered Notary in supporting and facilitating an electronic transaction (Cybernotary), not only as the bearers of the message of trust (Trusted Third Party, "T3P") but also as having a notary's service providers themselves electronically (electronic Notary). In the most minimal role, Notary only as parties to a legal identity verification and legalization someone (Registration Authorities) before the relevant awarded a Certificate of Electronic Organizer Electronic Certificate ("PSE"). Meanwhile, in the role of the maximum, exactly Notary itself became an organized party services electronically. Many countries have them, not only for the inherited system of Common Law Civil Law but, even in the second international forum Notary different models are currently developing temunya point for international trade in electronic container-apostilles. Qualitative study of the legal normative-analytical prekriptif, the empowerment examines the function and role of the Notary in a transaction that is supported by the presence of electronic systems by performing comparative PSE, and then find solutions to the obstacles faced by so it can be applied in Indonesia. Corresponding characteristics of the national legal system, in the short term may act as notary services supporting the implementation of electronic certification (RA) and in the notary can be a suborganization of the electronic certification service itself (sub-Certification Authority). In the long run, a chance for Notaries to conduct notary services electronically, including electronic authentic deed, as has been done by France and the United States.
\end{abstract}

Keywords: cybernotary, electronic notary, umbrella of trust 


\begin{abstract}
Abstrak
Untuk mencegah penipuan (fraud) tengah berkembang penggunaan suatu metode otentikasi secara elektronik (electronic authentication) yang terwujud dalam teknologi Tanda Tangan Elektronik dan Sertifikat Elektronik.("SE") sebagai sistem pengamanan transaksi yang dilakukan melalui sistem komunikasi elektronik. Demi efektifitasnya tujuan itu, telah banyak negara memberdayakan fungsi dan peran Notaris dalam mendukung dan memfasilitasi suatu transaksi elektronik (Cybernotary), tidak hanya sebagai pihak pengemban amanat kepercayaan (Trusted Third Party, "T3P") melainkan juga sebagai pihak yang menjadi penyedia jasa kenotariatan itu sendiri secara elektronik (electronic notary). Dalam peran yang paling minim, Notaris hanya sebagai pihak yang melakukan verifikasi dan legalisasi identitas hukum seseorang (Registration Authorities) sebelum yang bersangkutan diberikan Sertifikat Elektronik dari suatu Penyelenggara Sertifikat Elektronik ("PSE"). Sementara, dalam peran yang paling maksimal, justru Notaris itu sendiri yang menjadi pihak yang menyelenggarakan jasanya secara elektronik. Banyak negara sudah menerapkannya, tidak hanya bagi negara yang mewarisi sistem hukum Common Law melainkan juga Civil Law, bahkan dalam forum internasional kedua model Notaris yang berbeda tersebut tengah mengembangkan titik temunya demi perdagangan internasional dalam wadah electronic-apostilles. Penelitian kwalitatif terhadap hukum normatif yang bersifat analitis-prekriptif ini, mengkaji pemberdayaan fungsi dan peran Notaris dalam suatu transaksi elektronik yang didukung oleh keberadaan sistem PSE dengan melakukan komparatif, dan kemudian mencari solusi terhadap berbagai hambatan yang dihadapi agar hal tersebut dapat diterapkan di Indonesia. Sesuai karakteristik sistem hukum nasional, dalam jangka pendek Notaris dapat berperan sebagai pendukung jasa penyelenggaraan sertifikasi elektronik (RA) dan dalam jangka Notaris dapat menjadi sub-penyelenggaraan jasa sertifikasi elektronik itu sendiri (sub-Certification Authority). Dalam jangka panjang, terbuka kesempatan bagi Notaris untuk menyelenggarakan jasa notarisnya secara elektronik, termasuk pembuatan akta otentiknya secara elektronik, sebagaimana yang telah dilakukan oleh Perancis dan Amerika Serikat.
\end{abstract}

Kata kunci:transaksi notaris secara elektronik, notaris secara elektronik, satu payung kepercayaan 


\section{Pendahuluan}

Saat ini, Indonesia telah memiliki Undang-undang Nomor 11 Tahun 2008 tentang Informasi dan Transaksi Elektronik ("UU ITE") yang telah diundangkan sejak tanggal 21 April 2008 lalu. Berdasarkan UU ITE, setiap orang dapat menggunakan Tanda Tangan Elektronik (e-signature) yang didukung oleh suatu jasa layanan sertifikasi elektronik (Certification Service Provider/"CSP"). Pada dasarnya, suatu tanda tangan elektronik berikut sistem sertifikasi elektroniknya, diselenggarakan untuk memperjelas identitas subyek hukum dan melindungi keamanan serta otentisitas Informasi elektronik. Esensinya adalah keberadaan suatu metode verifikasi dan otentikasi untuk mengidentifikasi subyek hukum berikut akuntabilitas atau reliabilitas sistem elektroniknya sesuai lingkup tujuan penggunaannya.

Sementara itu, Notaris sebagai pejabat umum berdasarkan UU No.30 Tahun 2004 tentang Jabatan Notaris ("UU Notaris") mempunyai fungsi dan peran yang penting dalam legalitas transaksi di Indonesia. Telah dipahami bahwa Notaris berfugsi sebagaimana layaknya pihak ketiga yang terpercaya (Trusted-ThirdParty/"TTP") dalam suatu transaksi. Jasa Notaris telah menjadi kebutuhan masyarakat, tidak hanya dalam pembuatan akta (contoh: pendirian Badan Hukum, wasiat, dan Jual Beli Tanah sebagai pejabat pembuat akta tanah), melainkan juga untuk menjadi penengah atau saksi dari transaksi yang dilakukan (contoh: penarikan undian).

Sesuai perkembangan teknologi, Notaris dapat berperan dalam transaksi elektronik via cyberspace (Cybernotary), sebagaimana dijumpai di berbagai negara, baik yang bertradisi Common Law maupun Civil Law. Sehubungan dengan Hague Agreement tahun 1961 tentang Apostille, dan International Forum on e-Notarization, e-Apostilles and Digital Evidence, juga telah diupayakan harmonisasi peranan Notaris dalam transaksi elektronik global, sehingga sekarang Cybernotary dan/atau $e$-notarization telah menjadi kata kunci demi terwujudnya $e$-Apostille untuk transaksi internasional.

Ironisnya, konsep Cybernotary di Indonesia masih dalam perdebatan. Walaupun teknologi memungkinkan peranan Notaris secara online dan remote, namun secara hukum hal tersebut seakan tidak dapat dilakukan. Oleh karena itu, fungsi dan peran Notaris dalam konteks transaksi elektronik menjadi sangat penting untuk dikaji secara mendalam, agar Notaris Indonesia dapat berperan secara global.

Penelitian ini akan melihat bagaimana fungsi dan peranan Notaris dalam penyelenggaraan jasa sertifikasi elektronik di beberapa negara, dan bagaimana upaya mengatasi berbagai hambatan yuridis berkaitan dengan kewenangan Notaris tersebut, 
agar Notaris Indonesia menjadi dapat berperan sebagaimana mestinya. Lebih detil isu akan dirumuskan dalam beberapa pokok permasalahan sebagai berikut:

1. Bagaimanakah konsep dan praktek penyelenggaraan transaksi elektronik yang menggunakan tanda tangan elektronik dan sertifikasi elektronik di beberapa negara secara umum?

2. Bagaimanakah sejarah dan praktek perkembangan penyelenggaraan Fungsi dan Peran serta penyelenggaraa jasa Notaris dalam transaksi elektronik, baik pada negara-negara yang mewarisi Common Law maupun negara-negara yang mewarisi Civil Law?

3. Bagaimanakah kemungkinan pemberdayaan fungsi dan peran Pejabat Umum Notaris dalam mendukung mendukung transaksi elektronik di Indonesia, berikut reformasi hukum yang perlu dilakukan untuk mengakomodir dinamika tersebut?

\section{Tujuan dan Manfaat Riset}

Selain secara teknis riset ini adalah untuk menjawab permasalahan tersebut di atas, secara teoritis dan akademis penelitian ini akan bermanfaat untuk mengembangkan khasanah pemikiran hukum tentang fungsi dan peranan Notaris berikut batasan keotentikan suatu informasi elektronik beserta nilai kekuatan pembuktian hukumnya. Sementara itu, secara praktis riset akan memberikan manfaat kepada para pemangku kepentingan (stakeholders), antara lain, yaitu; (i) bagi penyelenggara jasa sertifikasi elektronik PSE (CA/CSP) dapat menjadi ukuran kwalitatif dalam menentukan standar penyelenggaraan sistem elektronik yang baik, khususnya dalam legal risk management, (ii) bagi Notaris, dapat menjadi tinjauan ilmiah tentang praktek penyelenggaraan jasa kenotariatan dalam lingkup transaksi elektronik; (iii) bagi masyarakat, dapat mengetahui kekuatan pembuktian hukum dari penggunaan sertifikat elektronik yang didukung oleh Notaris; (iv) bagi pemerintah, dapat menjadi petunjuk dalam mengharmoniskan UU Notaris dengan UU ITE; (v) bagi pihak yang bertransaksi, dapat mengetahui kepastian hukum dalam bertransaksi; dan (vi) bagi para penegak hukum (Hakim, Jaksa, dan Pengacara, Arbiter/Mediator), dapat berguna untuk menjelaskan validitas dan kekuatan pembuktian dari alat bukti digital atau elektronik. 


\section{Tinjauan Pustaka}

Dewasa ini, transaksi konvensional yang menggunakan kertas telah berubah menjadi bentuk transaksi yang menggunakan sistem elektronik. Hal tersebut sejalan dengan kesepakatan global dalam forum UNCITRAL. UNCITRAL adalah singkatan dari (United Nation Commission on International Trade Law) yang telah lama memberikan rekomendasi adanya nilai hukum pada suatu informasi dan/atau dokumen elektronik. ${ }^{1}$

UNCITRAL telah menggulirkan Model Law on E-Commerce (1996) ${ }^{2}$, dan Model Law on E-Signatures (2001), ${ }^{3}$ United Convention on the Use of ECommunication in International Contracts (2005), ${ }^{4}$ dan kajian tentang Promoting Confidence in E-Commerce: Legal Issues on International Use of Electronic Authentication and Signature Methods (2009). ${ }^{5}$ Kajian tersebut mengemukakan pentingnya harmonisasi untuk menyelesaikan isu metode otentikasi secara global agar tercipta suatu kepercayaan dalam berniaga secara elektronik (e-commerce). Kajian tersebut menyinggung peranan notaris publik dalam mencapai efektifitas ecommerce dan memperlihatkan pentingnya Hague Agreement 1961 tentang The Convention Abolishing the Requirement of Legalisation for Foreign Public Documents, yang mengarahkan setiap otoritas publik yang berkompeten (termasuk notaris) untuk melakukan simplifikasi dan format standar ("Apostille") dalam mensertifikasi keotentikan suatu dokumen publik.

Secara teknis, keotentikan pada umumnya dipahami hanya jika terhadap suatu proses penciptaan informasi dilakukan dengan prosedur formil yang ketat. Sementara umumnya, para ahli hukum akan mengatakan bahwa suatu informasi yang otentik

1 Official Records of the General Assembly, Fortieth Session, Supplement No. 17 (A/40/17), chap. VI, sect. B. 11 Dec 1985), ["the recommendation on the legal value of computer records"].

2 United Nations, UNCITRAL Model Law on Electronic Commerce with Guide to Enactment 1996 with additional article 5 bis as adopted in 1998, (New York: United Nations Publication, 1999).

3 United Nations, UNCITRAL Model Law on Electronic Signatures with Guide to Enactment 2001, (New York: United Nations Publication, 2002).

${ }^{4}$ United Nations, United Nations Convention on the Use on Electronic Communications in International Contracts, (New York: United Nations Publication, 2007).

5 United Nations, Promoting Confidence in Electronic Commerce: Legal Issues on International Use of Electronic Authentication and Sisgnature Methods, (New York: United Nations Publication, 2009). 
hanya terdapat dalam suatu akta otentik yakni akta yang dibuat oleh atau dilakukan dihadapan pejabat yang berwenang dalam wilayah hukumnya dan dalam bentuk/format sebagaimana yang ditentukan oleh UU (ps. $1868 \mathrm{KUHPerdt}$ ).

Menurut Retnowulan Sutantio, ${ }^{6}$ Akta otentik selama ini dipahami mempunyai 3 (tiga) aspek, yakni: (i) kekuatan pembuktian formil, karena membuktikan antara para pihak bahwa mereka sudah menerangkan apa yang ditulis dalam akta tersebut, (ii) kekuatan pembuktian materiil karena membuktikan antara para pihak bahwa benar-benar peristiwa yang tersebut dalam akta telah terjadi; dan (iii) kekuatan pembuktian keluar yang mengikat, karena keberlakuannya juga mengikat kepada pihak ketiga diluar para pihak. Sementara hal yang tidak jauh berbeda juga diutarakan oleh GHS Lumban Tobing, bahwa akta otentik mempunyai 3 (tiga) kekuatan pembuktian, (i) kekuatan pembuktian lahiriah, karena akta itu sendiri mampu membuktikan sendiri keabsahannya; (ii) kekuatan pembuktian formal karena akta tersebut dijamin kebenaran formalnya oleh pejabat sebagaimana yang telah diuraikannya dalam akta, dan (iii) kekuatan pembuktian material karena akta tersebut memuat substansi/isi yang lengkap dan dianggap kebenaran (kepastian sebagai yang sebenarnya) untuk diberlakukan kepada setiap orang atau pihak ketiga.

Berkenaan dengan itu, secara teknis sesungguhnya keotentikan suatu informasi elektronik ditentukan oleh akuntabilitas atau sejauhmana reliabilitas terhadap sistem elektronik itu sendiri. Hal ini sejalan dengan pendapat Prof. Smith seorang ahli Computer Security, yang menyatakan "Where information is recorded by mechanical means without the intervention of a human mind, the record made by the machine admissible in evidence, provided of course, it is accepted that the machine is reliable." Sementara itu, Bajaj \& Nag melihat bahwa validitas suatu informasi elektronik tetap berpijak kepada beberapa prinsip sistem komunikasi yang aman (secured communication), yakni: Confidentiality, Integrity, Authorization, Availability, Authenticity, Non-repudiation, dan Auditability (CIAANA). ${ }^{8}$ Selaras dengan itu, Stephen Mason memperhatikan adanya perbedaan bobot nilai pembuktian terhadap tanda tangan elektronik (Weight of Evidence), dimana kekuatan

6 Retnowulan Sutantio dan Iskandar Oeripkartawinata, "Hukum Acara Perdata dalam Teori dan Praktek", (Bandung: CV Mandar Maju, 1997), hal. 67-68.

7 Michael Chissick \& Alistair Kellman, "E-commerce: Law \& Practice", 2nd ed, (London: Sweet W. Maxwell, 2004), hal. 190.

${ }^{8}$ Kamles K Bajaj \& Debjani Nag, "E-commerce: the Cutting Edge of Business", (tanpa kota: tanap penerbit, 2000), hal. 198-199. 
pembuktian akan sangat ditentukan oleh karakteristik teknologi pengamanannya. Semakin penuh dalam menjalankan prinsip tersebut (CIAANA) maka akan semakin kuat nilai pembuktiannya. ${ }^{9}$

Mason juga mengemukakan bahwa Cyber-Notary pada awalnya merupakan gagasan American Bar Association Information Security Committe (1994), ${ }^{10}$ yang dilandaskan pada:

(a) Trust when transacting between parties over the internet;

(b) the security of the transmission;

(c) the integrity of the content of the communication; and

(d) the confidence that such transactions will receive legal recognition, so that a binding contract is enforceable. ${ }^{11}$

Lebih jauh Lawrence Leff mengemukakan bahwa yang dikonsepkan oleh ABA dengan "Cybernotary" adalah seseorang yang mempunyai kemampuan spesialisasi dalam bidang hukum dan komputer. Fungsinya dipersepsikan sebagaimana layaknya Notaris Latin dalam memfasilitasi suatu transaksi internasional. Dalam konteks PKI. ia akan mengikatkan antara private key dari si pengirim dengan public key dari si penerima dibawah satu payung kepercayaan ("umbrella of trust"). Cybernotary akan melakukan otentikasi dokumen secara elekronik, bahkan Cybernotary juga diharapkan dapat memverifikasi kapasitas hukum dan tangggung jawab keuangannya sehingga keluarlah usulan bahwa persyaratannya selayaknya adalah seorang pengacara (attorney). ${ }^{12}$

Sementara itu, Leslie Smith mengemukakan bahwa istilah "electronic notary" digulirkan oleh delegasi Perancis dalam forum TEDIS legal workshop pada konferensi EDI yang diselenggarakan oleh European Union tahun 1989 di Brussel. Esensinya adalah adanya suatu pihak yang menyajikan independent record terhadap suatu transaksi elektronik yang dilakukan para pihak. Technology

9 Stephen Mason, “Electronic Signatures in Law”, (Lexis-nexis UK 2003), hal. 274-329.

10 Information Security Committee of the American Bar Association, Section of Science and

${ }^{11}$ Ibid., hal. 74.

${ }^{12}$ Laurence Leff (ed.), "Notaries and Electronic Notarization", (Western Illinois University 2002), PDF [wd-spectools-docbook-template-03.pdf], <http://www.oasis -open.org/spectools/docs >. 
The term "electronic notary" is relatively new term in commerce and first appears to have been coined by the French delegation to the TEDIS (Trade Elecronics Data Interchange System) legal workshop at the European Union's 1989 EDI Conference in Brussels, where the concept of such an activity was introduced. This conference proposed that various industry associations and related peak bodies could act as an "electronic notary" to provide an independent record of electronic transactions between parties, i.e. when company a electronically transmits trade documents to company $B$, and vice versa. ${ }^{13}$

Secara umum apabila gagasan Cybernotary ataupun E-notary dapat dimplementasikan di Indonesia, maka kekuatan pembuktian informasi dan transaksi elektronik yang selama ini seringkali dipersepsikan mempunyai nilai pembuktian yang lemah akan menjadi lebih kuat kedudukannya karena dapat dipahami sebagaimana layaknya akta otentik. Hal tersebut akan meningkatkan kepercayaan dan keamanan masyarakat terhadap transaksi elektronik. Meskipun peluang notaris untuk berperan secara elektronik seakan tak terlihat dalam UU Notaris, namun sekiranya ada peraturan perundang-undangan lain yang memberikan peluang itu (contoh: PP yang diamanatkan UU-ITE memberikan peluang bagi Notaris untuk memberikan dukungan jasa layanan sertifikasi elektronik), ${ }^{14}$ maka hal tersebut sesungguhnya masih sangat relevan dengan ketentuan Pasal 15 ayat (2) butir (a) dan ayat (3) UU Notaris yang telah memberikan adanya kewenangan lain bagi Notaris sepanjang sesuai dengan peraturan perundang-undangan. ${ }^{15}$

${ }^{13}$ Leslie Smith, "The Role of the Notary in Secure Electronic Commerce, Information Security Institute Faculty of Information Technology", (Queensland University of Technology, September 2006), hal. 1.

${ }^{14}$ Salah satu kemungkinannya adalah sebagai pihak yang melakukan pengesahan tanda tangan elektronik dalam proses pendaftarannya (Registration Authorities/RA), atau dalam konteks tertentu bahkan sebenarnya Notaris juga dapat berperan menjadi sub-penyelenggara terhadap transaksi yang dilakukan diantara klien mereka sendiri.

15 Tampak jelas bahwa peluang untuk pemberdayaan peranan notaris dalam transaksi elektronik sebenarnya masih terbuka lebar dan sangat dibutuhkan masyarakat. Namun demikian masih ada beberapa permasalahan (tantangan) prinsip hukum yang harus diteliti secara mendalam, yaitu tentang persyaratan kehadiran secara fisik dalam pembuatan akta dan melakukan tandatangan, pembatasan wilayah kewenangan notaris, kesiapan infrastruktur, dan standar kompetensi teknis yang dibutuhkan. Sebagai pejabat umum yang mengemban amanat publik, tentunya Notaris harus mengembangkan prosedural yang ketat untuk itu. 
Selain itu beberapa permasalahan hukum yang terkait dengan penyelenggaraan kerja notaris secara konvensional selama ini, juga akan terselesaikan dengan baik. Tidak hanya terkait dengan perbaikan sistem pemberkasan karena penggunaan electronic filing melainkan juga karena sistem pencatatan dan standar penyelenggaraan jasa yang semakin efisien dan lingkup peluang transaksi yang semakin global. Notaris juga akan dipermudah dan diperkaya dengan fasilitas sistem elektronik yang menunjang bukti-bukti dari dipenuhinya syarat-syarat suatu keotentikan baik terhadap syarat obyektif maupun syarat subyektif, seperti antara lain; sistem penelusuran tentang validitas informasi subyek hukum, sistem pendaftaran perusahaan, sistem pengecekan dan pendaftaran akta tanah, sistem pelaporan/penyampaian salinan elektronik, dan lain sebagainya. Pada dasarnya efektifitas peran Cybernotary akan membutuhkan adanya infrastruktur sistem elektronik dan juga kepastian interkoneksi dan akses notaris kepada Sistem Registrasi Publik (Public Registries) yang terkait, seperti antara lain: data kependudukan, catatan pertanahan, dan lain sebagainya.

\section{Metodologi Riset}

Penelitian ini adalah penelitian kwalitatif yang akan meneliti keberadaan norma-norma hukum yang berlaku berdasarkan hukum positif. Alat penelitian yang digunakan dalam riset ini adalah penelusuran literatur atau studi kepustakaan (mencakup bahan hukum primer dan bahan hukum sekunder), berikut studi kasus yang ditemukan, serta dilengkapi dengan wawancara untuk mengetahui pemahaman para pemangku kepentingan.

Penelitian ini melihat kepada fungsi dan perannya notaris secara elektronik maka perlu diteliti lebih dahulu tentang bagaimana konsep dan penyelenggaraan transaksi elektronik dengan penggunaan tanda tangan elektronik pada umumnya. Hal tersebut adalah karena sesungguhnya penyelenggaraan Tanda tangan elektronik adalah infrastruktur dari keberadaan Cybernotary ataupun Electronic Notary. Kemudian baru diteliti lebih lanjut bagaimana perkembangan peran dan fungsi Notaris dalam lingkup tersebut. Setelah melihat catatan komparatif semua perkembangan tersebut maka dilakukan penelaahan terhadap kendalan apa yang dihadapi dan usulan perbaikan hukum yang diperlukan.

Penelitian ini akan mengambil enam sample negara yang mewarisi tradisi hukum yang berbeda; (i) tiga negara yang menggunakan sistem common law (US, UK, Australia) dan (ii) tiga negara yang menggunakan sistem civil law (Perancis,

Belanda dan Jerman). Terhadap masing-masing negara dikenali bagaimana 
karakteristik sistem hukum nasionalnya dalam mengatur fungsi dan peran Notaris Publik di negara yang bersangkutan baik konvensional maupun elektronik. Kemudian eksistensi Notaris Publik tersebut dianalisa konsistensi hukumnya berdasarkan undang-undang yang berlaku di tiap negara, dan sepanjang dimungkinkan jika dapat diakses, maka akan dilihat sampai dengan peraturan pelaksanaannya.

Selain itu, akan dilakukan pula wawancara dengan para pihak yang kompeten (antara lain; Ikatan Notaris Indonesia, PT. Telkom, Federasi Teknologi Informasi Indonesia (FTII), Pejabat Kementerian Komunikasi dan Informatika cq Dirjen Aplikasi Telematika, pejabat Kementerian Hukum dan HAM cq Ditjen Administrasi Hukum Umum, para praktisi hukum dan e-commerce serta masyarakat penggunanya. Selain narasumber dalam negeri, penelitian ini juga melakukan kunjungan penelitian dan mewawancarai narasumber di luar negeri, terutama kolega akademisi perguruan tinggi di luar negeri yang mempunyai keahlian di bidang ini (Tilburg University, Namur University, Antwerpen University).

Setelah bahan literatur dan hasil wawancara terkumpul dan diolah, dilakukan Diskusi Ahli Terarah (Focus Group Discussion) dengan beberapa narasumber yang dipandang ahli. Diskusi tersebut akan membahas mengenai temuan awal yang dihasilkan oleh Tim Periset dan meminta masukan dari para narasumber mengenai temuan tersebut. Hasil diskusi tersebut akan diolah kembali untuk melengkapi dan menyempurnakan hasil riset. Terakhir, Tim Periset akan menyusun rekomendasi yang praktis yang dapat langsung dilaksanakan oleh para pihak yang berkepentingan.

\section{Hasil Dan Pembahasan}

\section{A. Konsep Dan Praktek Penyelenggaraan Transaksi Elektronik Dengan Penggunaan Tanda Tangan Elektronik Dan Sertifikasi Elektronik}

Transaksi elektronik sudah menjadi bagian dari kehidupan sehari-hari, baik secara domestik maupun lintas negara. Transaksi elektronik, telah memiliki ketentuan hukum baik secara nasional (ps 1320 KUHPerdt dan UU-ITE) maupun secara internasional dengan berlakunya United Nations Convention on the Use of Electronic Communication in International Contracts pada tahun 2005 (selanjutnya disebut "Electronic Communication Convention" atau disingkat dengan "ECC"). Berdasarkan historikalnya, dapat dikatakan ECC 
adalah bentuk lanjut dari kelahiran UNCITRAL Model Law of E-commerce (1996) dan E-signatures (2005).

Dipandang dari sudut pandang komunikasi suatu transaksi elektronik pada dasarnya adalah suatu kegiatan pertukaran informasi melalui sistem komunikasi elektronik yang ditujukan untuk melakukan suatu perbuatan hukum tertentu. Perbuatan hukum tersebut dapat dilaksanakan dalam konteks: (i) hubungan penyelenggara negara kepada publiknya (pelayanan publik) atau (ii) dilakukan hubungan perdata para pihak untuk melakukan perikatan atau kontrak elektronik. Pada dasarnya baik untuk pelayanan publik maupun privat, suatu komunikasi elektronik yang bersifat privat hanya antara para pihak saja (baik B2B, B2C, C2C, G2C). Konsekwensinya terhadap komunikasi tersebut dipersyaratkan adanya jaminan suatu komunikasi yang aman (secured communication) yang mempersyaratkan adanya: (i) keotentikan suatu pesan (authenticity), (ii) otorisasi kewenangan atau kapasitas hukum pihak yang melakukan (authorization), (iii) kerahasiaan pesan yang dikomunikasikan (confidentiality), (iv) keutuhan pesan yang dikomunikasikan (integrity), (v) ketersediaannya (availability) dan (vi) tak dapat disangkal (non-repudiation). Semua syarat tersebut difasilitasi dengan penggunaan suatu metode otentikasi secara elektronik yang disebut dengan "electronic authentication" atau "electronic signatures".

Secara teknis, sesungguhnya keberadaan suatu 'tanda tangan' adalah merepresentasikan adanya suatu tindakan verifikasi dari si penandatangan terhadap apa yang ditandatanganinya, karenanya penandatangan selayaknya membaca terlebih dahulu dan memeriksa informasi tersebut kemudian membubuhkan indentitas dirinya sebagai subyek hukum yang bertanggung jawab atas informasi tersebut. Tindakan penandatanganan tersebut juga memperlihatkan adanya suatu niatan (intention) atau persetujuan dari si penandantangan terhadap sesuatu, baik terhadap substansi informasi yang terkandung didalamnya maupun terhadap konteks tujuan penggunaan tandatangan tersebut.

The notions of "authentication" and "authenticity" are generally understood in law to refer to the genuineness of a document or record, that is, that the document is the "original" support of the information it contains, in the form it was recorded and without any alteration. Signatures, in turn, perform three main functions in the paperbased environment: signatures make it possible to identify the signatory (identification function); signatures provide certainty as to 
the personal involvement of that person in the act of signing (evidentiary function); and signatures associate the signatory with the content of a document (attribution function). Signatures can be said to perform various other functions as well, depending on the nature of the document that was signed. For example, a signature might attest to the intent of a party to be bound by the content of a signed contract; the intent of a person to endorse authorship of a text (thus displaying awareness of the fact that legal consequences might possibly $\mathrm{fl}$ ow from the act of signing); the intent of a person to associate him or herself with the content of a document written by someone else; and the fact that, and the time when, a person has been at a given place.

Dalam perkembangannya, hasil kajian dari UNCITRAL memperlihatkan adanya beberapa pengertian dari beberapa negara tentang apa yang dimaksud "electronic authentication" tersebut, yaitu:

\begin{tabular}{|c|c|c|}
\hline $\begin{array}{l}\text { The Technology Administration of } \\
\text { the United States Department of } \\
\text { Commerce, for example, defines } \\
\text { electronic authentication as "the } \\
\text { process of establishing confidence } \\
\text { in user identities electronically } \\
\text { presented to an information } \\
\text { system" (United States, } \\
\text { Department of Commerce, } \\
\text { Electronic } \\
\text { AuthenticationGuideline: } \\
\text { Recommendations of the National } \\
\text { Institute of Standards and } \\
\text { Technology, NIST Special } \\
\text { Publication800-63, version 1.0.2 } \\
\text { (Gaithersburg, Maryland, April } \\
\text { 2006), available at } \\
\text { http://csrc.nist.gov/publications/nis } \\
\text { tpubs/800-63/SP800-63V1_0_2.pdf } \\
\text { (accessed on 5 June 2008)). }\end{array}$ & $\begin{array}{l}\text { The Government of Australia } \\
\text { developed an electronic } \\
\text { authentication framework that } \\
\text { defines electronic } \\
\text { authentication as "the process } \\
\text { of establishing a level of } \\
\text { confidence in whether a } \\
\text { statementis genuine or valid } \\
\text { when conducting a transaction } \\
\text { online or by phone. It helps } \\
\text { build trust in an online } \\
\text { transaction by giving the } \\
\text { parties involved some } \\
\text { assurance that their dealings } \\
\text { are legitimate. These } \\
\text { statements might include: } \\
\text { identity details; professional } \\
\text { qualifications; or the delegated } \\
\text { authority to conduct } \\
\text { transactions" (Australia, } \\
\text { Department of Finance and } \\
\text { Administration, Australian } \\
\text { Government e-Authentication }\end{array}$ & $\begin{array}{l}\text { Authentication prepared by } \\
\text { the Government of Canada, } \\
\text { for instance, define } \\
\text { authentication as "a process } \\
\text { that attests to the attributes } \\
\text { of participants in an } \\
\text { electronic communication or } \\
\text { to the integrity of the } \\
\text { communication". Attributes, } \\
\text { in turn, are defi ned as } \\
\text { "information concerning the } \\
\text { identity privilege or rights of } \\
\text { a participant or other } \\
\text { authenticated entity" } \\
\text { (Canada, Industry } \\
\text { Canada,Principles for } \\
\text { Electronic Authentication: a } \\
\text { Canadian Framework } \\
\text { (Ottawa, May 2004), } \\
\text { available at } \\
\text { http://strategis.ic.gc.calepic/ } \\
\text { sitelecic- }\end{array}$ \\
\hline
\end{tabular}

${ }^{16}$ [UNCITRAL Promotion, hal. 5 point 7]. 


\begin{tabular}{|l|l|l|}
\hline & Framework: An Overview & ceac.nsflen/h gv00240e.html \\
& (Commonwealth of Australia, & (accessed on 5 June 2008). \\
& 2005), available at & \\
& http://www.agimo.gov.au/infra & \\
& structure/ authentication/ & \\
& agaf_b/overview/introduction\# & \\
& e-authentication (accessed on 5 & \\
June 2008)). & \\
\hline
\end{tabular}

Tabel 2: Perbedaan Pengertian E-authentication dari Beberapa Negara ${ }^{I}$

Berdasarkan semua definisi tersebut kita dapat menarik suatu hal yang berlaku umum, yakni adanya suatu proses untuk menciptakan kepercayaan (confidence) dengan cara melakukan verifikasi terhadap: (i) informasi yang ditandatangani dengan pengidentifikasian terhadap identitas subyek hukum; (ii) pengamanan integritas informasi yang dikomunikasikan, dan jika digunakan untuk bertransaksi maka akan (iii) memperlihatkan adanya niatan persetujuan ataupun otorisasi terhadap pemanfaatan tanda tangan tersebut. ${ }^{18}$

Tidak jauh berbeda dengan konvensional, pada dasarnya suatu tanda tangan elektronik adalah berfungsi sama sebagaimana layaknya suatu tandatangan di atas kertas. Hal ini disebut dengan istilah "functional equivalent approach" yakni suatu pendekatan yang mempersamakan suatu tandatangan elektronik secara fungsional dengan suatu tandatangan elektronik di atas kertas.

Sesuai perkembangan teknologi, terdapat beberapa moda tentang suatu tanda tangan elektronik, yakni; (i) penggunaan tanda tangan digital yang berbasiskan enkripsi suatu pesan (digital signatures); (ii) penggunaan tanda yang unik pada

\section{${ }^{17}$ Ibid.}

${ }^{18}$ Sebagaimana lazimnya suatu tanda tangan secara konvensional, maka paling tidak dipahami beberapa fungsi yakni: (i) fungsi simbolik tentang pembubuhan identitas suatu subyek hukum yang bertanggung-jawab, bahwa apa yang dituliskan atau disampaikan adalah merepresentasikan karakteristik identitas dari seseorang (contoh: mungki/n saja terdapat beberapa nama orang yang sama, namun ekspresi tanda tangannya akan selalu berbeda); (ii) fungsi otentikasi bahwa apa yang ditandatanganinya telah dibacanya dan diketahuinya serta dikunci dengan keberadaan pencantuman namanya (contoh: dalam pembuatan suatu perjanjian maka terdapat paraf setiap halaman yang telah dibacanya); (iii) fungsi persetujuan bahwa tindakan penandatanganan adalah penjelmaan dari suatu tindakan persetujuan atau penerimaan terhadap konten didalamnya; dan (iv) fungsi pembuktian bahwa selanjutnya bahwa konten atas informasi tersebut akan menjadi bukti hukum bagi para pihak yang menggunakannya; 
anggota badan (biometric), (iii) penggunaan kata kunci (passwords) ataupun kombinasinya (hybryd methods), dan (iv) tanda tangan yang dipindai secara elektronik (scanned signatures) atau pengetikan nama pada suatu informasi (typed names).

Semua jenis tanda tangan elektronik, secara teknis mempunyai level kekuatan pembuktian yang berbeda sesuai kaedah-kaedah yang berlaku dalam secured communication. Semakin jelas sistem keotentikannya yang berdampak kepada kepastian nir-sangkal maka semakin kuat tingkat dan bobot pembuktiannya. Dalam prakteknya keberadaan suatu metode jika tidak melibatkan pihak ketiga tentunya tetap saja meyimpan potensi adanya penampikan dari yang bersangkutan. Oleh karena itu, hal tersebut perlu ditunjang dengan keberadaan suatu sertifikasi elektronik yang diselenggarakan oleh pihak ketiga (Certification Service Provider) sebagai pihak pengemban amanat kepercayaan tersebut (Trusted Third Party).

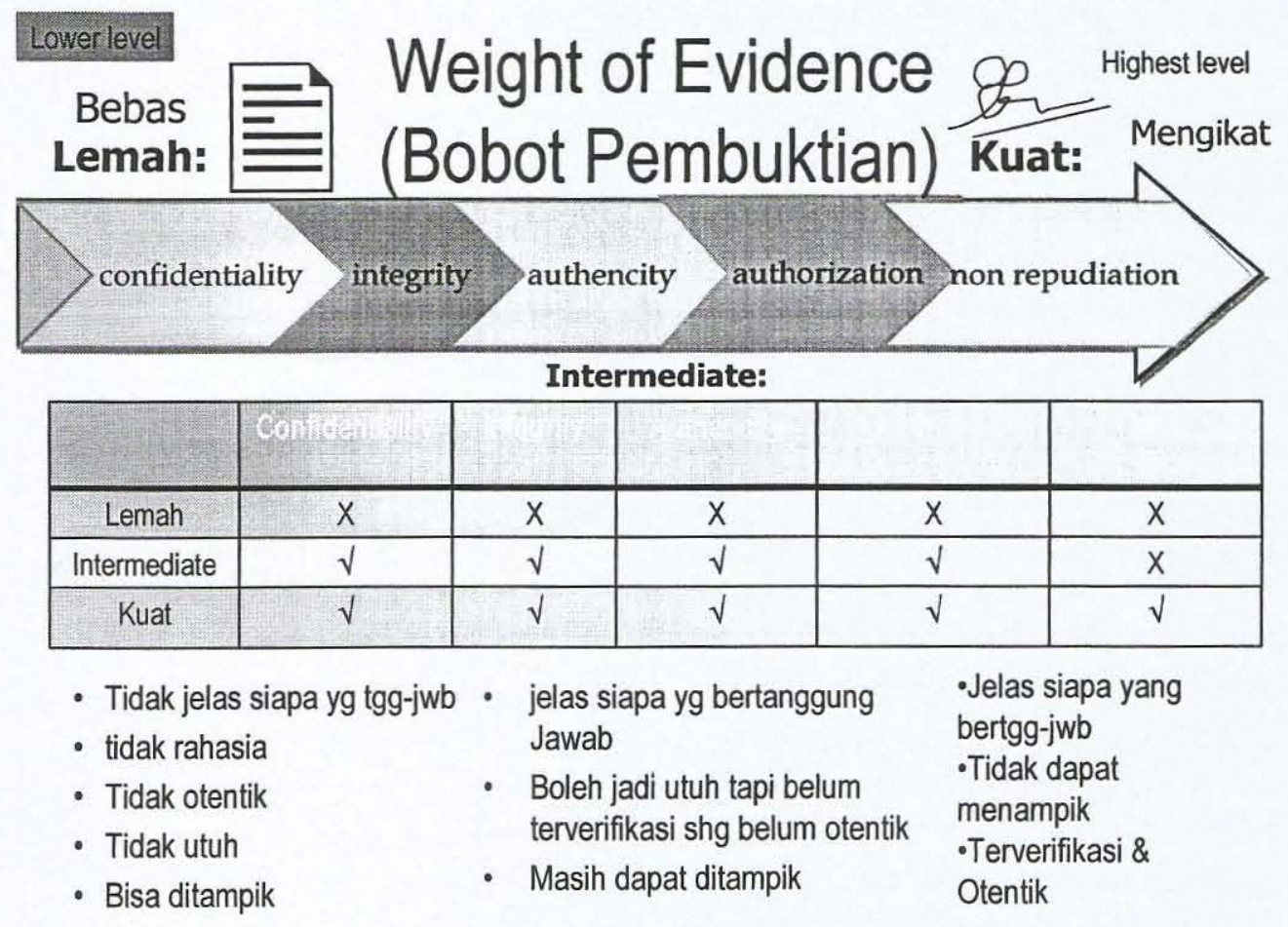

Gambar 6: Tingkatan Kekuatan Pembuktian 
Sehubungan dengan itu, terdapat beberapa ketentuan hukum yang mengatur tentang penyelenggaraan tanda tangan elektronik baik secara internasional (UNCITRAL dan ECC), regional (Eorepan Community Directive) maupun nasional (contoh: UETA di AS, Digital Signature Act di Malaysia, Electronic Transaction Act di Singapore dan UU-ITE di Indonesia). Dalam penelitian ini, perlu diperhatikan beberapa karakteristik perbedaan paradigma dan pengaturan dari perumusan hukum tentang TTE dan TE tersebut.

Pada dasarnya, dapat dibedakan adanya tiga pendekatan dalam pengaturan tentang TTE, khususnya dengan melihat kekuatan pembuktian dari suatu informasi elektronik, yakni: (i) minimalist approach (functional equivalent approach); (ii) technology specific approach, dan (iii) two-tiered or twopronged approach. Ketiga pendekatan tersebut akan menjadi acuan dalam membuat kebijakan publik suatu negara untuk melakukan tingkatan pengakuan hukum dan kekuatan pembuktiannya.

\section{A. Pendekatan Minimalis (Minimalist Approach)}

Pendekatan minimalist diperkenalkan oleh UNCITRAL Model Law of E-commerce (1996) dan UNCITRAL Model Law on Electronic Signatures (2001) yang menganut asas netral teknologi. Model ini telah diikuti oleh banyak negara, dimana prinsipnya adalah sistem hukum yang berlaku harus dapat mengkomodir semua jenis teknologi penyelenggaraan tanda tangan elektronik dengan melakukan pendekatan kesetaraan fungsional. Pendekatan ini disebut sebagai pendekatan minimalis karena memberikan pengakuan dan status hukum kepada semua jenis tanda tangan elektronik. Fokusnya lebih mengarah kepada persyaratan fungsional kerja dan metode otentisitas bukan kepada penyebutan teknologi tertentu (contoh tanda tangan digital).

Ketentuan UNCITRAL Model Law menekankan setidaknya pada dua fungsi utama dari tanda tangan elektronik, yaitu: (i) untuk mengidentifikasi penandatangan, dan (ii) untuk menunjukkan maksud dari penanda tangan sehubungan dengan informasi yang ditandatangani. Selanjutnya ketentuan telah menjadi suatu kesepakatan global dengan lahirnya ECC, yang tegas menyatakan bahwa suatu komunikasi elektronik selayaknya mendapat pengakuan hukum atau tidak dapat ditampik hanya dengan alasan sematamata bahwa bentuknya yang elektronik. 
Transaksi yang menggunakan komunikasi elektronik untuk kontrak internasional, berdasarkan article $9 \mathrm{ECC}$, tidak harus mempersyarakatkan dalam suatu bentuk baku tertentu (particular form). Yang utama harus diselesaikan paradigmanya adalah bagaimana syarat konvensional suatu transaksi yang selama ini dilakukan dengan media kertas dapat dipenuhi, yakni (i) tertulis (writing), (ii) bertanda-tangan (sign) dan (iii) asli (original). Ketiga syarat tersebut selanjut dapat dipersamakan secara fungsional dengan keberadaan suatu informasi elektronik yang dikomunikasikan secara elektronik apabila memenuhi beberapa syarat yang ditentukan sebagai berikut:

\section{Article 9 Form requirements}

1. Nothing in this Convention requires a communication or a contract to be made or evidenced in any particular form.

2. Where the law requires that a communication or a contract should be in writing, or provides consequences for the absence of a writing, that requirement is met by an electronic communication if the information contained therein is accessible so as to be usable for subsequent reference.

3. Where the law requires that a communication or a contract should be signed by a party, or provides consequences for the absence of a signature, that requirement is met in relation to an electronic communication if:

(a) A method is used to identify the party and to indicate that party's intention in respect of the information contained in the electronic communication; and

(b) The method used is either:

(i) As reliable as appropriate for the purpose for which the electronic communication was generated or communicated, in the light of all the circumstances, including any relevant agreement; or

(ii) Proven in fact to have fulfilled the functions described in subparagraph (a) above, by itself or together with further evidence.

4. Where the law requires that a communication or a contract should be made available or retained in its original form, or provides consequences for the absence of an original, that requirement is met in relation to an electronic communication if: 
(a) There exists a reliable assurance as to the integrity of the information it contains from the time when it was first generated in its final form, as an electronic communication or otherwise; and

(b) Where it is required that the information it contains be made available, that information is capable of being displayed to the person to whom it is to be made available.

5. For the purposes of paragraph $4(a)$ :

(a) The criteria for assessing integrity shall be whether the information has remained complete and unaltered, apart from the addition of any endorsement and any change that arises in the normal course of communication, storage and display; and

(b) The standard of reliability required shall be assessed in the light of the purpose for which the information was generated and in the light of all the relevant circumstances. ${ }^{19}$

Dalam proses pembuktiannya, semua prinsip tersebut akan sangat tergantung kepada pemahaman hakim, arbiter atau otoritas publik, dalam menerapkan "uji kepatutan reliabilitas" (appropriate reliability test). Dalam uji ini, semua jenis tanda tangan elektronik yang memenuhi persyaratan dianggap sah sepanjang memenuhi syarat fungsionalnya. Dengan kata lain penerapan uji reliabilitas itu sendiri adalah perwujudan dari prinsip netralitas teknologi. UNCITRAL e-signatures juga memberikan panduan dalam melihat suatu tingkat keandalan yang layak ("trustworthiness") dari penyelenggaraan CA/CSP:

\section{Article 10. Trustworthiness}

For the purposes of article 9, paragraph $1(f)$, of this Law in determining whether, or to what extent, any systems, procedures and human resources utilized by a certification service provider are trustworthy, regard may be had to the following factors:

(a) Financial and human resources, including existence of assets;

(b) Quality of hardware and software systems;

(c) Procedures for processing of certificates and applications for certificates and retention of records; 


\section{(d) Availability of information to signatories identified in certificates and to potential relying parties; \\ (e) Regularity and extent of audit by an independent body; \\ (f) The existence of a declaration by the State, an accreditation body or the certification service provider regarding compliance with or existence of the foregoing; or \\ (g) Any other relevant factor. ${ }^{20}$}

\section{B. Pendekatan Dua Jenjang (Two-tiered Approach)}

Pendekatan dua jenjang dianut oleh negara-negara dalam Komunitas Eropa, khususnya dengan keberadaan Directive 1999/93/EC tentang Electronic Signatures. Dalam pendekatan ini, aturan menetapkan adanya suatu ambang rendah persyaratan untuk suatu metode otentikasi elektronik dan menerima status hukum minimum tertentu serta memberikan suatu akibat hukum yang lebih besar untuk metode otentikasi elektronik tertentu yang lebih tinggi atau terakreditasi (penyebutannya bisa beragam seperti "secured", "advanced" atau "qualified" atau "accredited"). Pada pokoknya, terdapat paling tidak dua jenis pemboboton, yakni (i) tingkat yang simpel atau biasa (ordinary), atau (ii) tingkatan yang lebih aman (advanced) ataupun terakreditasi.

${ }^{20}$ Ibid., [Lebih lanjut dalam prakteknya, UNCITRAL juga memperlihatkan berbagai ragam faktor hukum, teknis dan komersial yang juga patut untuk dipertimbangkan untuk melihat penyelenggaraan suatu metode atau teknologi tertentu dari suatu tanda tangan oleh Penyelenggaranya (CA/CSP) apakah berada dalam situasi dan kondisi yang menawarkan suatu tingkat keandalan yang layak ("trustworthiness"), antara lain sebagai berikut: (a) kecanggihan peralatan yang digunakan oleh masing-masing pihak; (b) sifat kegiatan perdagangan mereka; (c) frekuensi transaksi komersial terjadi antara pihak; (d) sifat dan ukuran transaksi; (e) fungsi persyaratan diberikan tanda tangan dalam undang-undang dan lingkungan regulasi, (f) kemampuan sistem komunikasi, (g) sesuai dengan prosedur otentikasi yang ditetapkan oleh perantara, (h) sejumlah prosedur otentikasi yang disediakan oleh setiap perantara; kepatuhan; (i) dengan kebiasaan perdagangan dan praktek; (j ) adanya mekanisme perlindungan asuransi terhadap pesan yang tidak sah; (k) pentingnya dan nilai dari informasi yang terdapat dalam pesan data, (l) ketersediaan alternatif metode identifikasi dan biaya pelaksanaan, dan (m) derajat penerimaan atau non-penerimaan metode identifikasi dalam industri yang terkait atau lapangan baik pada saat metode ini disepakati dan pada saat pesan data yang dikomunikasikan. 


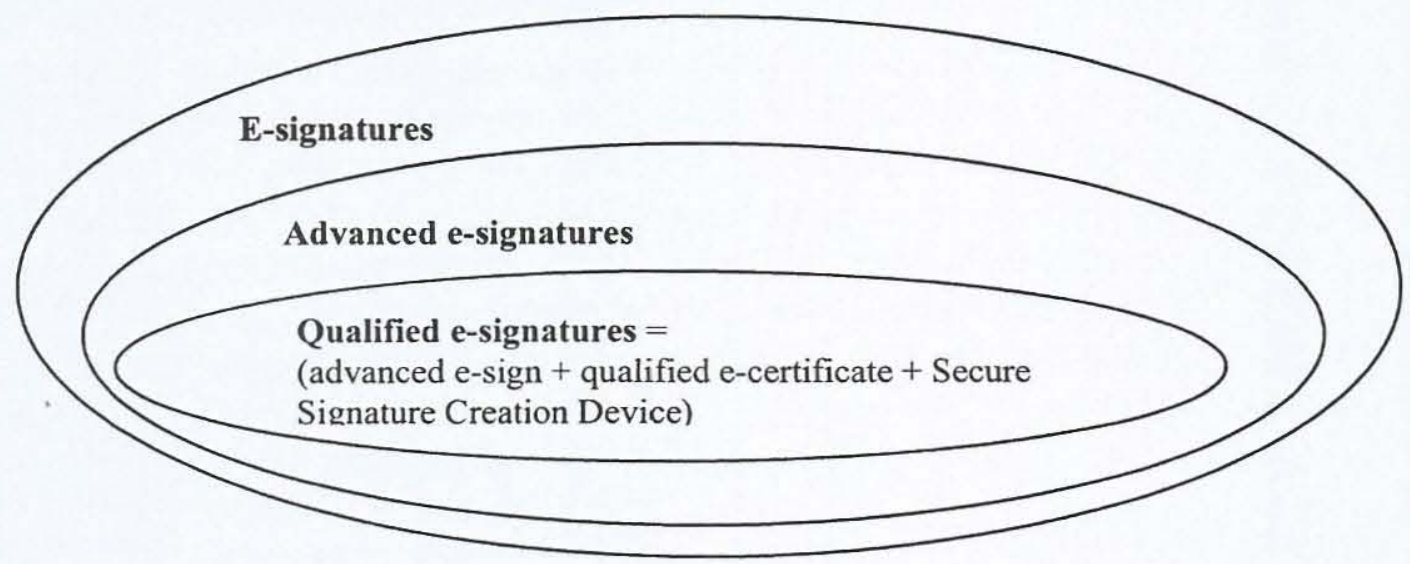

Gambar 1: Diagram Kwalifikasi E-signatures

Pada tingkatan yang dasar, undang-undang tetap mengadopsi sistem kesetaraan-fungsional (functional equivalent approach) dengan tanda tangan konvensional, Hal ini dibangun dengan berdasarkan pada prinsip teknologi netral. Namun UU juga menerima keberadaan tingkatan tanda tangan yang lebih tinggi, yang didasari atas "rebuttable presumption," dimana terhadap penyelenggaraan sistem yang telah terakreditasi maka TTE dianggap dengan serta merta setara dengan tanda tangan basah kecuali dapat dibuktikan sebaliknya. EC Directive memberikan panduan mengenai kriteria pengakuan tanda tangan elektronik yang didukung oleh sertifikat yang terakreditasi (qualified certificate). ${ }^{21}$

\section{Pendekatan Berbasiskan Teknologi Tertentu/Tanda Tangan Digital}

Pendekatan berbasiskan teknologi tertentu adalah paradigma pengaturan e-signature yang hanya merujuk kepada suatu jenis teknologi tertentu saja yakni penggunaan tanda-tangan digital dengan Public Key Infratructure (PKI) (contoh: Digital Signature Act di Utah suatu Negara bagian di AS, dan Malaysia). Teknologi Tanda Tangan Digital dengan penggunaan kriptografinya, saat ini adalah teknis yang paling sempurna dalam menjawab kebutuhan akan secured communication dan sudah

\footnotetext{
${ }^{21}$ Lihat lampiran tabel Annex I-IV EC Directive tentang E-signatures.
} 
terbukti keandalannya. Banyak negara yang sudah menerapkannya, namun dalam prakteknya hal tersebut belum tertentu berbanding lurus dengan kebutuhan atau kesadaran masyarakatnya. Dalam konteks B2B atau B2C, antara investasi untuk itu dengan pengembalian investasinya cenderung tidak sepadan. Biaya untuk membangun atau menyelenggarakan PKI relatif mahal sementara pengembalian investasinya tidak mudah karena pemanfaatannya oleh masyarakat belum dirasakan sebagai kebutuhan. Oleh karena itu, hidupnya model bisnis PKI pada dasarnya adalah sangat tergantung pada hubungan komunikasi elektronik dalam konteks layanan publik kepemerintahan. Dengan kata lain tumbuh subur dan efektifitasnya PKI adalah sangat tergantung kepada komunikasi antara Pemerintah dengan Warga Negaranya.

Keuntungan dari kebijakan yang dibangun dengan penggunaan TTD adalah hubungan komunikasi yang lebih aman dengan tingkat keamanan yang relatif tinggi. Namun pada sisi lain ia mendatangkan kerugian kepada penggunaan teknologi TTE yang lain karena seakan teknologi selain TTD menjadi direndahkan pengakuan nilai hukumnya. Kelemahan lain adalah terkuncinya paradigma masyarakat terhadap teknologi tertentu saja padahal peluang inovasi TTE seharusnya tetap berkembang. Dalam konteks TTD, produk legislasi khusus biasanya berpihak pada penggunaan tanda tangan digital dalam PKI. Pola pembangunan struktur PKI adalah cukup bervariasi dari masing-masing negara. Hal tersebut sesuai dengan tingkat intervensi pemerintahnya, setidak UNCITRAL memperlihatkan adanya tiga model utama, yakni (i) Model Swa-regulasi (self regulation), ${ }^{22}$ (ii) Peranan Pemerintah Yang Dibatasi (limited government involvement), ${ }^{23}$ dan (iii)

22 Berdasarkan model ini, bidang usaha untuk jasa otentikasi dibiarkan terbuka lebar. Sementara pemerintah dapat membentuk satu atau lebih skema otentikasi dalam departemen sendiri dan organisasi terkait, sektor swasta bebas untuk mengatur skema otentikasi, komersial atau sebaliknya, sesuai tujuannya. Tidak ada kewajiban mempunyai otoritas otentisitas tingkat-tinggi ( $h i g h$ level authentication authority) dan penyedia layanan otentikasi (authentication service provider) bertanggung jawab untuk memastikan interoperabilitas dengan penyedia jasa otentikasi lainnya baik secara domestik maupun internasional, tergantung pada tujuan pembentukan skema otentikasi itu sendiri. Tidak ada persyaratan perijinan (lisensi) atau persetujuan yang diperlukan dari pemerintah terhadap pemilihan atau penggunaa teknologi oleh penyedia layanan otentikasi (kemungkinan pengecualian hanya yang terkait dengan peraturan perlindungan konsumen);

${ }^{23}$ Dalam model ini, Pemerintah dapat memutuskan untuk mendirikan otoritas tingkat tertinggi otentikasi baik secara sukarela ataupun wajib. Dalam hal ini, penyedia layanan otentikasi tentunya 
peranan pemerintah yang optimal dan memimpin proses pengembangan (government led process). ${ }^{24}$

Dari ketiga pola tersebut, sangat menarik mengkaji apa yang terjadi di Eropa, dimana pemerintahan negara-negara anggota European Union sedang mengupayakan penyelenggaraannya untuk saling interoperable dan compatible satu sama lain, khususnya dalam konteks "e-ID management" guna lebih memberdayakan masyarakat dalam mengakses layanan publik yang diselenggarakan oleh negaranya. Beberapa model Manajemen e-ID dapat digambarkan dalam beberapa konteks pendekatan, antara lain (i) pendekatan akses pengguna tradisional (traditional user access

akan merasa perlu untuk berinteroperasi dengan otoritas otentikasi tingkat tinggi untuk memiliki bukti bahwa otentikasi mereka (atau otentikator lainnya) dapat diterima di luar sistem mereka sendiri. Dalam hal ini, spesifikasi teknis dan manajemen dari penyedia layanan otentikasi harus segera dipublikasikan secepat mungkin oleh Pemerintah sehingga pemerintah dan sektor swasta dapat saling menyesuaikan rencananya masing-masing. Dalam konteks ini adanya syarat perijinan (Lisensi) dan persetujuan lebih dahulu dari pemerintah terhadap teknologi yang akan digunakan oleh setiap penyedia layanan otentikasi adalah suatu konsekwensi logis yang terjadi;

24 Dalam model ini, Pemerintah berhak memutuskan untuk mendirikan sebuah penyedia layanan eksklusif otentikasi pusat (exclusive central authentication service provider). penyedia otentikasi dengan tujuan khusus (special-purpose authentication service provider) juga hanya dapat dibentuk dengan persetujuan pemerintah terlebih dahulu (approval). Model ini lazim diterapkan dalam kontek Sistem Identitas Manajemen kependudukan (electronic-ID) di negara maju. Pemerintah secara langsung dapat mengakibatkan penggunaan tanda tangan elektronik menjadi aplikatif karena diterapkan dalam kehidupan sehari-hari, khususnya dalam kepentingan warga negara untuk dapat mengakses layanan publik yang diselenggarakan oleh pemerintah. Beberapa negara telah meluncurkan program untuk menerbitkan identitas elektronik (e-ID) kepada warga negaranya yang diberikannya dalam media yang aman (contoh: chip/smart-card) sehingga dapat dibaca oleh sistem elektronik mereka. 
approach ${ }^{25}$ dan (ii) Pendekatan berdasarkan tipe jasa layanan (services
approach).

Berbagai upaya tengah dilakukan untuk memperluas keberlakuan identity management baik di tingkatan bisnis maupun tingkatan pemerintahan. Namun, kebijakan pilihan dalam dua skenario mungkin cukup berbeda jauh. Pendekatan oleh pemerintah, misalnya, mungkin akan lebih berorientasi pada pelayanan publik yang lebih baik guna memenuhi kebutuhan warga negaranya dan karenanya cenderung melakukan interaksi dengan orang secara fisik. Sebaliknya, pendekatan dalam konteks bisnis justru cenderung untuk mengurangi interaksi secara fisik. Oleh karenanya dengan mempertimbangkan kebutuhan akan aplikasi komersial, maka terlihat bahwa ada kecenderungan semakin meningkatnya penggunaan mesin otomatis dalam melakukan transaksi bisnis. Oleh karena itu, merekeka mungkin akan mengadopsi fitur-fitur yang dimaksudkan guna dapat mengakomodasi kebutuhan spesifik dari mesin-mesin itu sendiri.

Sehubungan dengan interoperabilitas teknis, International Telecommunication Union telah membentuk kelompok fokus pada manajemen identitas untuk memfasilitasi dan memajukan pengembangan kerangka manajemen identitas yang bersifat generik dan sarana penemuan identitas terdistribusi mandiri dan federasi identitas dan implementasinya. Sementara itu solusi manajemen e-ID juga tengah dikembangkan dalam

25 Pendekatan ini mengikuti paradigma akses online kedalam jaringan secara konvensional (log-on), dan biasanya didasarkan pada penggunaan informasi yang terkandung dalam perangkat seperti kartu pintar (smart-card) atau dimiliki oleh pelanggan dan yang pelanggan gunakan untuk logon ke layanan. Pendekatan akses pengguna kepada sistem manajemen e-ID berfokus pada administrasi otentikasi pengguna, hak akses, pembatasan akses, profil account, password dan atribut lainnya dalam satu atau lebih aplikasi atau sistem. Hal ini bertujuan untuk memfasilitasi dan mengendalikan level akses ke aplikasi dan sumber daya sambil melindungi informasi pribadi dan bisnis rahasia dari pengguna yang tidak berhak;

${ }^{26}$ Pendekatan ini merupakan suatu paradigma yang lebih inovatif, dan didasarkan pada sistem yang memberikan layanan pribadi kepada pengguna dan perangkatnya. Dalam pendekatan ini, ruang lingkup manajemen identitas menjadi lebih luas dan mencakup semua sumber daya perusahaan yang digunakan untuk memberikan layanan online (seperti; peralatan jaringan, server, portal, konten, aplikasi dan produk), sebagaimana halnya aspek kredensial pengguna (user's credentials), buku alamat, preferensi dan alas hak. Dalam prakteknya, bisa juga meliputi, misalnya, informasi yang berkaitan dengan pengaturan kontrol orangtua (parental control settings) dan partisipasi dalam program-program loyalitas. 
rangka e-government sebagai contohnya adalah upaya-upaya yang telah dibangun oleh Komunitas Eropa. ${ }^{27}$

Dalam perkembangannya seiring dengan EC Directive 2006 tentang Services, khususnya dalam rangka menjawab harmonisasi legislatif untuk mengembangkan internal market eropa, semua negara anggota wajib saling mengakui atau menerima CA/CSP yang terakreditasi di negaranya masingmasing. Cara pertama adalah dengan menyiapkan daftar CA yang terakreditasi ("trusted list"), kemudian mereka tengah bekerja agar sistem tersebut saling interoperable satu dengan lainnya agar dapat memfasilitasi cross-border-certification. ${ }^{28}$

Belakangan ini Eropa tengah menggulirkan proyek STORK (Secure idenTity acrOss boRders linKed) dengan tujuan untuk menjamin crossborder recognition terhadap masing-masing electronic identity ("e-ID") dari setiap negara guna lebih memberdayakan akses terhadap public services dari 13 negara anggota. Pola yang mereka pakai adalah mengacu kepada kesuksesan model jaringan Credit Card (Visa dan Master). Mereka membuka peranan pihak swasta untuk dapat mengelola peluang usaha turunannya, dimana mereka akan menerapkannya dalam kinerja empat element. Beberapa element diselenggarakan oleh pemerintah, dan beberapa elemen lagi diserahkan kepada swasta agar menimbulkan kesempatan peluang usaha. Model ini diharapkan dapat lebih mensemarakan penggunaan TTE di masyarakat.

${ }^{27}$ Semua negara komunitas Eropa (European Community) terikat pada ketentuan EC Directive 1999/93/EC tentang E-signatures ("E-sign Directive") dan Directive 2006/123/EC tentang services in the Internal Market ("ESD") serta ETSI Standard (TS 101456 untuk qualified certificate dan ETSI 102023, ETSI TS 101-861 tentang policy requirements for time stamping authorities, demi interoperabilitas dari ("qualified e-signature") dan "advanced e-signature based on Qualified Certificate".

${ }^{28}$ EC Directive [The Services Directive aims to achieve a better internal market for enterprises by guaranteeing two freedoms: (i) freedom of establishment, and (ii) the freedom to provide services throughout the entire EU. It aims to eliminate the existing barriers to cross-border business, including administrative burdens, legislative uncertainty and lact of mutual trust. To be able to achieve this goal, the Services Directive describes the following three main requirements to met by each of the EU member states: (i) development of fair national requirement for enterprises.(ii) development of a single point of contact for enterprises.(iii) development of a solution to identify users (with a high level of security) of electronic services and to process request of enterprises online. 


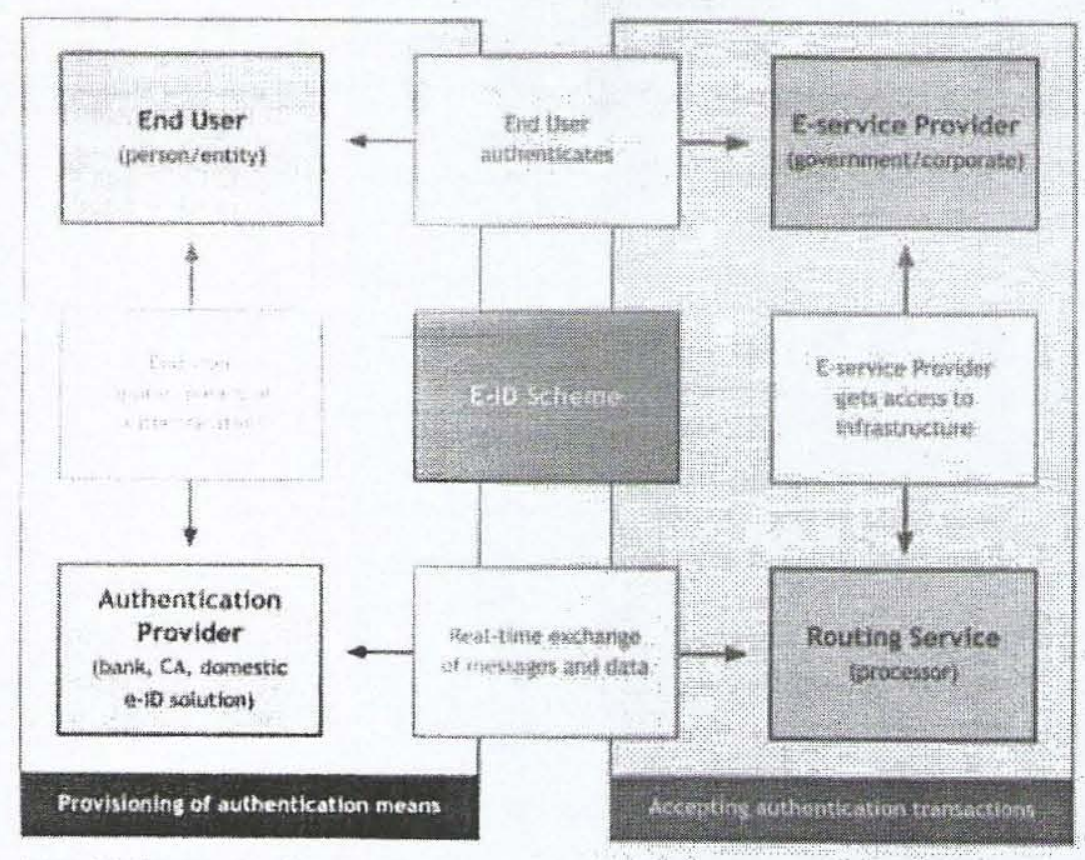

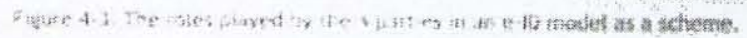

\section{Gambar 3: Skema e-ID Management}

Semula model 3-party adalah menjadi kelaziman dalam penyelenggaraan $e-I D$, dimana hanya terdapat satu pihak sebagai sentral yang memperantarai hubungan dari Konsumen dan Pedagang. Dalam perkembangannya Eropa cenderung akan lebih memilih 4-party model, mereka mengharapkan akan lebih banyak memberikan manfaat diantaranya adalah membuka pasar yang kompetitif dan memperluas jangkauan serta efek jaringan, khususnya terhadap routing service dan authentication provider.

A 4-party model ensures the separation of the parties providing the service for the two sides of the network: the authentication providers serves the End User and the Routing Service serves the E-service Provider. In the model, these two roles can now be played by differents parties, which have the following benefit: (i) the model prevents the development of a centralised position of power; (ii) the model allows the re-use of already existing means of authentication; (iii) an End-user can use one 
authentication means of choice to identify himself at multiple organizations resulting in high-user friendliness and reduction of the "digital key ring." (iv) stimulate the market (v) developed in competition are always inter-operable;(vi) prevents competition on an infrastructure level; (vii) freedoms of choice for all-users of the e-ID network. ${ }^{29}$

Sebagai konsekuensi dari inisiatif seperti yang dijelaskan di atas, maka sebagian besar warga negara dapat menerima perangkat TTE atau Sertifikat Elektronik dengan kemampuan yang aman dan dengan biaya rendah. Meskipun tujuan utama dari inisiatif $e-I D$ mungkin tidak ditujukan untuk komersial, namun dalam prakteknya perangkat tersebut juga dapat digunakan dalam lingkup dunia komersial. Oleh karena itu, tampaknya aplikasi dari dua domain (komersial dan non-komersial) juga akan semakin konvergen.

\section{Kekuatan Pembuktian terhadap Informasi Elektronik}

Pada dasarnya dengan mempertimbangkan doktrin dari Prof. Smith tentang computer security dan juga kaedah-kaedah dalam secured communication (CIANAA), maka dapat dikatakan adanya spektrum dalam kekuatan pembuktian dari suatu informasi elektronik berikut komunikasi elektroniknya, dari suatu tingkatan yang paling rendah (hanya sebagai barang bukti) sampai dengan tingkatan yang paling tinggi (alat bukti yang berdiri sendiri). Secara teknis, meskipun dilengkapi dengan sistem yang canggih untuk menciptakan keyakinan terhadap suatu TTE dan Sertifikat Elektronik, pada dasarnya hal tersebut akan berpulang lagi kepada kaedah hukum nir-sangkal, yakni jika hanya dilakukan oleh kedua belah pihak yang berkomunikasi tanpa melibatkan pihak ketiga, maka tetap saja ada peluang bagi salah satu pihak untuk melakukan penyangkalan. Oleh karena itu, untuk memastikan tidak dapat disangkal lagi, maka diperlukan peranan pihak ketiga sebagaimana layaknya notaris dalam penggunaan tandatangan elektronik dalam transaksi tersebut.

Berdasarkan pemikiran tersebut di atas, ringkasnya dapat dipahami bahwa ada keterhubungan antara suatu Informasi Elektronik dengan Tanda Tangan Elektronik dengan fungsi dan peran pihak ketiga berikut peranan notaris serta perhimpunannya:

\footnotetext{
${ }^{29}$ Ministry of Economic Affairs, A Network Approach to E-identification, The Hague, 2009.
} 
1. Keberadaan suatu IE yang lemah adalah informasi yang tidak jelas siapa subyek hukum yang bertanggungjawab padanya dan tidak jelas apakah informasi itu terjaga keutuhannya.

2. Keberadaan suatu IE yang cukup kuat nilai pembuktian hukumnya adalah yang melekat padanya suatu tanda tangan elektronik sebagai sistem yang mampu mengidentifikasi siapa subyek hukum yang bertanggung jawab berikut kejelasan pengamanan terhadap informasi itu sendiri (identification \& authentication/integrity). Terhadap hal ini diberlakukan pendekatan yang minimalis yakni pendekatan kesetaraan fungsional secara "tertulis" dan "asli";

3. Sementara suatu TTE yang mempunyai nilai pembuktian yang kurang kuat adalah TTE yang tidak melibatkan peranan suatu pihak ketiga yang layak dipercaya (trusted third parties) keberadaanya hanya antara para pihak yang membuat dan menerimanya;

4. Suatu TTE yang mempunyai nilai pembuktian yang cukup kuat adalah apabila melibatkan peranan suatu pihak ketiga yang layak dipercaya (trusted third parties) yang didukung dengan keberadaan suatu Sertifikat Elektronik di dalamnya (ordinary signature);

5. Selanjutnya, suatu Sertifikat Elektronik (e-certificate) yang paling kuat adalah apabila penyelenggara CSP dan Certificate-nya telah memenuhi akreditasi pada suatu negara dimana ia digunakan (qualified certificate).

6. Sementara peranan pihak T3P yang paling kuat adalah apabila mereka menyertakan fungsi dan peran notaris di dalamnya, paling tidak sebagai pemeriksa dan legalisasi identifikasi seseorang dalam proses pendaftaran dan perolehan certificate (RA) di dalamnya. Proses ini akan menjamin bahwa pihak yang mengajukan sertifikat adalah orang yang benar dan memastikan yang bersangkutan menerimanya secara langsung.

7. Sedangkan peranan fungsi notaris yang paling kuat dalam mendukung suatu Transaksi Elektronik adalah apabila mereka dapat bertindak hanya sebagai sebagai RA melainkan juga mempunyai kewenangan untuk membuat suatu akta secara elektronik; 
8. Akhirnya fungsi dan peran Ikatan Notaris yang paling kuat adalah apabila mereka dapat bertindak menjadi $\mathrm{CA}$ atau sub-CA bagi para notaris yang menjadi anggotanya.

\section{E. Urgensi Peranan Notaris Dalam Transaksi Elektronik}

Fungsi dan peran sebagaimana layaknya Notaris, dalam konteks transaksi elektronik dijalankan oleh pelaku CA/CSP. Lembaga ini mengemban amanat (trust) dari masyarakat terhadap keberadaan informasi ID seseorang yang disampaikannya. Sayangnya hal tersebut dalam perspektif dan kinerja teknis semata, maka sangat diperlukan peranan notaris untuk mendukungnya agar informasi yang disampaikan oleh CA/CSP substansinya dapat dikatakan sebagaimana layaknya suatu akta otentik, khususnya apabila tidak ada penyangkalan dari pihak yang terkait daripadanya.

Urgensi fungsi dan peran notaris secara elektronik juga mengemuka pada International Congress XXIV dari Latin Notaris tahun 2004 yang sempat dibahas dalam Working Group untuk Theme II ("The Notary and electronic contracts"), pada pokoknya menyadari untuk membuka diri dengan mengakomodir semua perkembangan tersebut dengan baik dengan tidak mengurangi ketentuan sebagaimana mestinya. Konferensi ini telah menyadari adanya kemungkinan pembuatan akta otentik secara elektronik. Seiring dengan itu pula tengah berkembang pembicaraan untuk e-apostille antara Notaris Common Law dan Civil Law sebagai titik temu dari Hague Convention 1961.

Berdasarkan Hague Convention Abolishing The Requirement Of Legalization For Foreign Public Documents (1961), dalam konteks private international law, terdapat ketentuan yang mempermudah tentang legalisasi dokumen dokumen publik yang digunakan dalam transaksi international. Hal tersebut dilakukan dengan mensimplifikasikan rantai keotentikan suatu dokumen publik (salah satunya adalah akta notaris).

The Convention simplifies the old "chain" authentication procedure which requires multiple seals to be place on documents, by eliminating many links in the chain. Documents which have the special Hague Legalization Certificate are 
acceptable in other countries where the treaty is in force without any other authentication. ${ }^{30}$

Meksipun Indonesia belum menjadi anggota konvensi Hague tentang Apostile, namun ketentuan dalam konvensi ini menjadi best-practices dalam pertukaran dokumen yang digunakan perdagangan internasional. Dalam perkembangannya, konvensi ini juga digunakan dalam konteks transaksi elektronik terhadap surat berharga pasar uang (securities). ${ }^{31}$ Manfaat konvensi Den Haag ini adalah memastikan bahwa ada jawaban yang jelas dan tertentu untuk pertanyaan seperti yang mengatur hukum penentuan sifat hukum hak-hak yang dihasilkan dari kredit efek ke rekening efek, langkah-langkah yang diperlukan untuk transfer atau penjaminan surat berharga untuk rekening tersebut yang akan dilaksanakan antara pihak dan pihak ketiga, dan langkah-langkah yang diperlukan untuk mewujudkan janji efek dikreditkan ke akun tersebut. Komisi Eropa sendiri telah menyimpulkan bahwa penerapan Konvensi akan kepentingan terbaik dari Komunitasnya dan merekomendasikan bahwa Konvensi perlu ditandatangani setelah atau dengan setidaknya dua mitra utama perdagangan, termasuk Amerika Serikat.

Dalam perkembangannya sekarang ini, Konvensi Den Haag tersebut akan dijadikan pijakan dalam melakukan pertukaran dokumen publik antar bangsa dan tengah dirumuskan terus ketentuan hukumnya dalam International Conference yang dilakukan secara rutin. Eropa dan AS cq National Notary Association (NNA) membangun project electronicApostille Pilot Program ("e-APP"). ${ }^{32}$

${ }^{30}$ Lihat UNCITRAL, Promoting confidence in electronic commerce: legal issues on international use of electronic authentication and signature methods, 2009 dan $\mathrm{HCCH}$.

${ }^{31}$ Adalah suatu fakta bahwa kebanyakan efek saat ini diadakan, ditransfer dan digunakan oleh suatu entri elektronik kedalam suatu rekening dengan sistem kliring dan penyelesaian dan perantara lain, daripada penyerahan langsung dalam bentuk fisik/langsung oleh emiten. Pasar keuangan global, yang bagi negara-negara OECD sendiri memiliki volume lebih dari \$ 2 milyar US setiap hari, sedang membutuhkan sebuah rezim hukum yang berurusan secara efektif dengan kenyataan baru. Ada kesepakatan luas dalam dunia keuangan bahwa aturan hukum tradisional, berdasarkan transfer fisik dan kepemilikan langsung sudah tidak memadai lagi karena terlalu beragam ketentuannya. Hasilnya adalah ketidakpastian hukum, peningkatan risiko, dan biaya yang lebih tinggi untuk kliring global dan penyelesaian, dengan dampak pada semua tingkat pasar keuangan global. 
Dalam program e-APP, Konferensi Den Haag dan NNA, bersamasama dengan setiap negara yang berkepentingan, mengembangkan, mempromosikan dan membantu dalam pelaksanaan model perangkat lunak berbasiskan "open source" untuk (a) penerbitan dan penggunaan $e$ apostilles, dan (b) operasi sistem pendaftaran atau pencatatan elektronik apostilles (e-register). Program ini mempertimbangkan dua format dan tatap-muka (interface) yang berbeda, namun tetap dengan tujuan yang sama yakni melindungi originalitas dokumen yang menjadi dasar diterbitkannya sertifikat e-apostille dari modifikasi yang tidak sah.

Dengan metode Pertama, otoritas yang berkompeten dapat menambahkan sertifikat apostille sebagai halaman eksternal file sebuah dokumen publik yang ada yang mendasari dalam format tertentu (e-APP), contoh Portable Document Format (PDF). Penerima akan membuka file dan menemukan sertifikat e-apostille sebagai halaman terakhir dari dokumen. Dalam format ini, dokumen publik yang mendasari dan bentuk sertifikat e-apostille merupakan satu dokumen tersendiri. Satu masih bisa memilih untuk mencetak satu atau lebih halaman ini sebagai file tunggal, dan jika ingin memilah sertifikasi e-apostille juga bisa dicetak sendiri olehnya.

Dengan metode kedua, dokumen publik yang mendasari terbitnya apostille dilampirkan sebagai file terpisah ke sertifikat e-apostille. Penerima masih menerima file PDF tunggal tetapi, saat membuka file tersebut, pengguna justru membuka sertifikat e-apostille dulu dan kemudian juga dapat membuka dokumen publik yang mendasarinya sebagai lampiran, dan melihatnya sebagai PDF file yang terpisah. Metode ini memberikan antarmuka yang lebih intuitif bagi penerima dokumen apostille. Dengan melampirkan dokumen publik yang mendasari sebagai file ke sertifikat e-apostille, tujuannya adalah untuk membuatnya sangat jelas kepada penerima ketika dia pertama membuka dokumen yang ia

${ }^{32}$ UNCITRAL, Promoting confidence in electronic commerce: legal issues on international use of electronic authentication and signature methods, 2009 [Komisi pada konvensi tersebut melihat manfaat dari penerapan TI untuk penyelenggaraan Apostille, yakni: (i) maintenance of a secure electronic database of signatures for the purpose of verifying the signature appearing on the public documents for which on Apostille is requested; (ii) for the use of word processing technology to complete the information which would appear on the Apostille; (iii) use of electronically reproduced signatures of the issuing authority which would be inserted through secure electronic means and printed on the Apostille; and (iv) the maintenance of electronic register]. 
hadapi ialah apostille, baru kemudian membuka dokumen publik yang mendasari untuk melihat isinya.

Pada negara-negara yang menjalankan konvensi ini, dapat dibayangkan pentingnya upaya untuk mengembangkan sistem dimana dokumen akta asing akan diberikan pengakuan hukum atas dasar verifikasi tanda tangan elektronik atau metode otentikasi yang digunakan oleh notaris dimana mereka berasal. Tanda tangan elektronik yang berasal dari notaris harus diverifikasi oleh pengguna dokumen (umumnya notaris lain) dengan cara yang sederhana dan cepat. Hal ini hanya dapat dilakukan melalui Internet dengan mengakses situs penyedia jasa sertifikasi dimana notaris tersebut berasal. Satu masalah yang cukup kritikal adalah terkait dengan verifikasi kewenangan notaris dimana ia berasal untuk otentikasi catatan di bawah sistem hukum di mana ia beroperasi. Dalam rangka memfasilitasi proses tersebut dan meniadakan kebutuhan untuk konsultasi badan pengawas asing, jika ada, maka hal tersebut dipercayakan dengan institusi pemberi izin notaris, telah diusulkan bahwa CA/CSP yang didirikan di bawah naungan Himpunan Notaris hanya mengeluarkan sertifikat ke notaris saat mereka masih berwenang untuk melaksanakan fungsi notaris, sehingga setiap penundaan atau pencabutan wewenang notaris secara otomatis harus mencegah verifikasi notaris tersebut terhadap suatu tanda tangan.

\section{(ii) Lingkup Aplikasi Domestik tentang Kegiatan Notarisasi dan Segelnya}

Sebagaimana diketahui bahwa pada dasarnya semua negara mempunyai prosedur pemeriksaan untuk menentukan tingkat kepercayaan terhadap tandatangan. Prosedur tersebut dalam konteks tertentu adalah suatu kewajiban (contoh: akta notaris), namun dalam konteks lainnya boleh jadi justru bersifat suatu pilihan saja atau "optional" (contoh: transaksi bawah tangan).

Most legal systems have special procedures or requirements that are intended to enhance the reliability of handwritten signatures. Some procedures may be mandatory in order for certain documents to produce legal effects. They may also be optional and available to parties that wish to act to preclude possible arguments concerning the authenticity of certain documents. Typical examples include the following: 
(a) Notarization. In certain circumstances, the act of signing has a particular formal significance due to the reinforced trust associated with a special ceremony. This is the case, for instance, with notarization, i.e. the certification by a notary public to establish the authenticity of a signature on a legal document, which often requires the physical appearance of the person before the notary;

(b) Attestation. Attestation is the act of watching someone sign a legal document and then signing one's name as a witness. The purpose of attestation is to preserve evidence of the signing. By attesting, the witness states and confirms that the person whom he or she watched sign the document in fact did so. Attesting does not extend to vouching for the accuracy or truthfulness of the document. The witness can be called on to testify as to the circumstances surrounding the signing;

(c) Seals. The practice of using seals in addition to, or in substitution of, signatures is not uncommon, especially in certain regions of the world. Signing or sealing may, for example, provide evidence of the identity of the signatory; that the signatory agreed to be bound by the agreement and did so voluntarily; that the document is final and complete; or that the information has not been altered after signing. It may also caution the signatory and indicate the intent to act in a legally binding manner. ${ }^{33}$

Sehubungan dengan itu, dalam perkembangannya sekarang ini beberapa negara telah menghapuskan adanya persyaratan tentang segel (seal) pada transaksi atas tanah yang dianggap sudah tidak lagi relevan dalam konteks saat ini. Hal tersebut telah digantikan dengan keberadaan suatu tanda tangan dari pihak ketiga yang menjalankan fungsi kesaksian (attestation/witnessed). Beberapa negara (contoh: Ireland) telah memiliki peraturan yang memungkinkan suatu tanda tangan elektronik yang aman (secured e-signature) untuk menggantikan peranan segel. Sejumlah negara bahkan telah meluncurkan inisiatif yang memfasilitasi penggunaan dokumen elektronik dan tanda tangan elektronik dalam transaksi tanah (contoh Belanda, Belgia dan Jerman), bahkan dalam undang-undang beberapa negara, juga diberikan kemungkinan penggunaan "segel elektronik" (electronic seals) sebagai alternatif dari segel manual (manual seal) yang diakui secara resmi, sedangkan rincian detil teknis dari bentuk segel elektronik diatur secara terpisah (contoh Inggris, Australia dan

${ }^{33}$ Ibid. 
Amerika).$^{34}$ Dari semua perkembangan itu, pada intinya dapat dikatakan bahwa aturan yang mempersyaratkan keberlakuan segel sudah tidak relevan lagi jika seseorang telah menggunakan TTE, karena teknologi TTE itu sendiri sudah berfungsi sebagai pengaman sebagaimana layaknya segel.

Sehubungan dengan itu pula, selaras dengan perkembangan teknologi informasi dan komunikasi, di beberapa negara yang mewarisi Civil law, kamar (chamber) atau himpunan notaris telah membentuk CA/CSP tersendiri untuk mendukung penggunaan TTE/TTD para notaris anggotanya dan bahkan kadang-kadang juga diberikan kepada publik (contoh: Italia, Spanyol, Jerman, Belgia, dan Perancis). Sedangkan terhadap akta yang dibuatnya dapat disampaikan salinannya secara elektronik oleh para notaris, selain para notaris itu sendiri menyimpan arsipnya, institusi terkait (pengawas) juga melakukan penghimpunan terhadap salinannya.

Beberapa negara telah melakukan perubahan sistem hukumnya untuk mengakomodir e-authentication. Beberapa negara merubah aturan dalam KUHPerdatanya, ${ }^{35}$ khususnya mengenai aturan tentang akta otentik (contoh: Perancis dan Belgia). Sementara beberapa negara lainnya melakukan perubahan pada UU Notarisnya (contoh: Belanda dan Jerman). Belgia dan Perancis telah merubah Pasal dalam KUHPerdt yang memberikan kemungkinan keberlakuan tanda tangan elektronik. Keberadaan Pasal tersebut menekankan kepada pendekatan minimalist (functional equivalent approach) dari keberadaan pengakuan hukum terhadap electronic signatures. Apapun teknologinya sepanjang memenuhi beberapa syarat utama (a.l: identification, content approval dan content integrity) maka hakim akan menerimanya sebagai alat bukti di pengadilan.

Meskipun telah tampak kemajuan dalam beberapa tahun terakhir, beberapa keraguan tampaknya masih tetap ada, khususnya tentang aturan bagaimana pembuatan akta transaksi secara secara elektronik dapat dikatakan sepenuhnya dapat setara atau memenuhi persyaratan unsur-unsur penting dari suatu akta otentik, antara lain: (i) kehadiran fisik dari para pihak dihadapan notaris untuk memastikan bahwa yang bersangkutan benar orangnya, (ii) pembacaan untuk mengetahui bahwa yang

\footnotetext{
${ }^{34}$ Amerika Serikat Uniform Real Property Electronic Recording Act tegas menyatakan bahwa bentuk fisik atau gambar elektronik dari suatu cap (stamp), kesan atau segel sebenarnya tidak dibutuhkan untuk menyertai suatu TTE. Pada dasarnya, itu semua hanya informasi tentang segel ketimbang keberadaan segel itu sendiri, sebagaimana yang dibutuhkan. Hal tersebut menentukan bahwa setiap undang-undang, peraturan atau standar yang membutuhkan adanya stempel pribadi atau perusahaan, kesan atau segel, dianggap telah terpenuhi dengan kehadiran tanda tangan elektronik.

${ }^{35}$ Lihat lampiran tabel perbandingan.
} 
bersangkutan memang mempunyai kapasitas hukum dan mengerti akan tindakannya, (iii) kehadiran saksi-saksi agar yang bersangkutan tidak dapat menampik kehadirannya pada transaksi tersebut.

Dalam kaitan itu, dapat dikatakan bahwa penerapan kriptografi dapat dikatakan menjadi sarana untuk itu. Kriptografi dapat digunakan untuk menjadi simbol dari adanya otorisasi dan consent para pihak. Namun masih ada beberapa aturan lain, yang membutuhkan adanya kehadiran para pihak berikut para saksi untuk dapat benar-benar melihat gambar tanda tangan mereka pada layar berikut gambar segel notaris yang harus tampil pada akhir prosesuil dari tindakan transaksi tersebut.

Asumsi bahwa kehadiran fisik sangat diperlukan bagi pembentukan sebuah akta otentik, masih menjadi tantangan bagi kemungkinan adanya adaptasi dari perkembangan TIK baik yang sudah ada maupun yang sedang berkembang untuk masa depan. Secara teknis, "kehadiran fisik" bukan tidak mungkin juga dapat dilakukan secara elektronik. Dengan melihat perkembangan mobile communication (3G) sekarang ini, setiap orang dapat melakukan panggilan video conference, dan dapat menanamkan tanda tangannya pada chip kartu telepon (SIM card) atau pada handset yang bersangkutan, dan dapat ditahui fakta riil dimana yang bersangkutan berada dengan fasilitas satelit melalui GPS ataupun utilitas map yang disediakan.

Selanjutnya berkenaan dengan adanya asas kehati-hatian yang tetap harus menyertai standar pekerjaan notaris, maka selain infrastruktur sistem yang telah terakreditasi atau disertifikasi, sebenarnya juga dibutuhkan adanya standar kemampuan bagi notaris yang ingin melakukan penyelenggaraan jasanya secara elektronik agar menjadi tidak keliru dalam penerapannya dan dapat mengantisipasi hal tertentu jika ternyata ada indikasi bahwa sistem tidak berjalan sebagaimana mestinya.

Menjadi suatu catatan penting bahwa baik AS maupun Perancis yang sudah cukup maju untuk membuat akta secara elektronik, ternyata juga masih meminta kehadiran semua pihak untuk berada langsung dihadapannya dan kemudian secara live melakukan pembuatan akta dengan sistem elektronik yang berada di kantor notaris. Pada dasarnya mereka pun masih belum memberikan ruang untuk pembuatan akta secara jarak jauh (remote). Peneliti menilai bahwa mungkin hal tersebut terjadi justru karena memang e-ID belum terselenggara dengan baik di Perancis sehingga tidak dapat dipastikan bahwa Subyek Hukum yang hadir secara elektronik dapat dikatakan sama dengan kehadiran fisik secara langsung. Jika seseorang yang tampil dalam video-conference telah sesuai antara penampakannya dengan photo yang terdapat pada persona data ID yang terdapat pada sumber data otentiknya (e-ID resources) yang dapat diakses online oleh Notaris, maka sulit mengatakannya adanya ruang untuk melakukan penolakan terhadap validitas data tersebut. Oleh karena itu, 
keberadaan remote transaction yang diaktakan secara elektronik, kedepannya jelas akan sangat mungkin terjadi.

\section{F. Perkembangan Notaris Konvensional dan Modern}

Meskipun ada sebagian ahli yang menyatakan bahwa sejarah notaris pertama tampaknya mungkin berawal dari Mesir berdasarkan temuan sejarah kertas papyrus yang digunakan pada administrasi negara zaman kerajaan Firaun (Pharaohs) jauh sebelum Isa dilahirkan, ${ }^{36}$ namun tidak dapat dipungkiri bahwa keberadaan notaris adalah pewarisan dari konsep sistem hukum Roma (scribae, notarius dan tabelliones) yang ternyata tidak hanya mempengaruhi negara Eropa Kontinental yang menganut sistem Civil Law melainkan juga negara-negara yang menganut Common Law. Contohnya adalah Inggris yang tampaknya tidak mewarisi hal tersebut, namun dalam perkembangannya mereka juga mempunyai ruang bagi Public Notary dengan Public Notary Act 1843.

Faktanya sekarang ini, baik negara-negara yang mewarisi Common Law maupun Civil Law, meskipun agak sedikit berbeda cara pandangnya terhadap fungsi dan peran notaris, namun mereka sama-sama mengenal keberadaan notaris sebagai pihak ketiga yang layak dipercaya untuk menjamin legalitas suatu perbuatan hukum.

Dalam prakteknya sekarang ini, Notaris sebenarnya tidak hanya memiliki peran dan kewenangan dalam transaksi yang konvensional, khususnya dalam pembuatan akta otentik saja, melainkan juga pekerjaan lain sebagaimana ditentukan oleh peraturan perundang-undangan. Bahkan dalam lingkup TI, di Belanda Notaris dapat menjadi pihak ketiga terpercaya dalam suatu transaksi elektronik (Trusted Third Party) atau menjadi escrow untuk source-code software komputer.

\begin{tabular}{|c|c|c|c|}
\hline Common Law & Civil Law & & Indonesia \\
\hline $\begin{array}{l}\text { - Meskipun Hukum Inggris } \\
\text { (Anglo-saxon) dan juga }\end{array}$ & $\begin{array}{l}\text { - mewarisi tradis } \\
\text { Law sehingga }\end{array}$ & $\begin{array}{l}\text { Romans } \\
\text { terdapat }\end{array}$ & $\begin{array}{l}\text { - Mewarisi tradisi Romans } \\
\text { Law akibat penjajahan }\end{array}$ \\
\hline
\end{tabular}

${ }^{36}$ Charles N. Faerber, Book Versus Byte: The Prospects And Desirability Of A Paperless Society, John Marshall Journal Of Computer \& Information Law [Vol. XVII, p. 797-831]. [The Louvre's famous statue of the seated Egyptian scribe - perhaps also history's first representation of a notary, albeit de facto - reminds us of the importance of papyrus writings in the governmental administration of the pharaohs]. 